\title{
Evaluation of Non-Point Source $N$ and $P$ Loads in a Small Mixed Land Use Land Cover Watershed
}

\author{
Ashok Mishra ${ }^{1}$, Rajendra Singh ${ }^{1}$, Vijay P. Singh ${ }^{2}$ \\ ${ }^{1}$ Agricultural and Food Engineering Department, Indian Institute of Technology, Kharagpur, India \\ ${ }^{2}$ Department of Biological and Agricultural Engineering \& Department of Civil \& Environmental Engineering, Texas \\ A \& M University, College Station, USA \\ E-mail: amishra19@yahoo.com,rsingh@agfe.iitkgp.ernet.in,vsingh@tamu.edu \\ Received August 10, 2009; revised September 8, 2009; accepted October 28, 2009
}

\begin{abstract}
Non-point source pollution (NPS) of water resources has become a major problem in recent years due to more human interactions and disturbances to natural landscapes. The problem can have more impacts in sub-humid subtropical regions where high intensity monsoon rains have greater effects on hydrologic processes and thus the assessment of those effects is necessitated for strategic water resources and environmental management. Since spatial and temporal changes of NPS pollutants are difficult to assess on a watershed scale, the assessment can be done effectively using a suitable water quantity-quality model coupled with GIS and remote sensing that incorporates spatial variations. The objective of this study was to assess the $\mathrm{N}$ and $\mathrm{P}$ loads from a small mixed type watershed comprising different land use land covers with the aid of Soil and Water Assessment Tool (SWAT)-a hydrologic-water quality model. The model was calibrated for runoff and sediment transport and then simulation of associated N and P loads as NPS pollution was done and compared with measured values at the outlet of the watershed which is part of the DVC Command, Hazaribagh, India. The calibrated SWAT model was used to estimate the water soluble $\mathrm{NO}_{3}-\mathrm{N}, \mathrm{NH}_{4}-\mathrm{N}, \mathrm{P}$, organic $\mathrm{N}$ and organic $\mathrm{P}$ loads being transported as pollutants by runoff and percolated water. The estimates of these pollutants provided information on the extent of NPS pollution of water downstream. The results of the study reveal that the NPS pollutant load in runoff varies with seasonal rainfall patterns and ranges from 2.57 to 4.52 $\mathrm{kg} / \mathrm{ha}$ in case of $\mathrm{NO}_{3}-\mathrm{N}$ which accounts for a maximum load of $7661.40 \mathrm{~kg}$ of $\mathrm{NO}_{3}-\mathrm{N}$ in surface runoff from the watershed under study. The total loss of $\mathrm{N}$ from the watershed accounts for as high as $8.84 \mathrm{~kg} / \mathrm{ha}$, whereas the P load is $0.02 \mathrm{~kg} / \mathrm{ha}$. These losses can be as high as $14984.14 \mathrm{~kg}$ of total $\mathrm{N}$ and $50.85 \mathrm{~kg}$ of total $\mathrm{P}$ when estimated as NPS pollutants from the watershed. The study is therefore important to get an estimate of the extent of these pollutants and develop measures for mitigating the losses as nutrient as well as pollution of water resources.
\end{abstract}

Keywords: Modeling, Watershed, Swat, N\&P Nutrient Load, NPS Pollution

\section{Introduction}

In humid and sub-humid subtropical regions in developing countries, such as India, intensive runoff and concomitant transport of sediment along with agro-chemicals (fertilizers, insecticides and pesticides) are rapidly degrading land resources and polluting water resources. The rate of pollutant runoff from the watershed changes in response to land use (LU)/land cover (LC) and the characteristics of rainfall [1-5]. Hence, knowledge of pollutant runoff mechanism as non-point sources (NPS) is needed to understand the nature and extent of pollution from watersheds, especially under rainy conditions. Since the hydrologic response of a watershed varies spatially and temporally, an intensive study of the watershed is necessary for developing the management scenario and also for transforming the results from one watershed to another having similar characteristics.

In agricultural as well as mixed type watersheds, the NPS pollution is largely generated by agricultural activities [6-9]. The United States Environmental Protection Agency (USEPA) reported that the routine agricultural activities were responsible for more than 60 percent of the surface water contamination [10]. In large water 
bodies, such as the Chesapeake Bay, the major NPS pollutants are sediment, nitrogen $(\mathrm{N})$ and phosphorus $(\mathrm{P})$ [11]. Fertilizers, animal wastes and crop residues are major sources of $\mathrm{N}$ and $\mathrm{P}$. Nitrate concentrations in surface and ground waters continue to be a matter of serious concern throughout the world [12-14]. In India high consumption of nitrogenous fertilizers and the resulting $30-50 \%$ losses of nitrogen [15] has also been reported to contaminate surface and ground water bodies [16-18].

The wide spread nature of NPS pollutants losses in response to hydrological processes and land use patterns makes their measurements difficult. In contrast with point source pollution, large volumes of data are required for the assessment and management of NPS pollution. As a result, NPS pollution is often assessed by modeling that combines a hydrologic model with Geographic Information System (GIS) and Remote Sensing (RS) techniques [19-22]. The advantage of RS and GIS techniques is that they obviate the need for cumbersome and time-consuming extraction of watershed parameters. RS provides information on land use/land cover, topography and GIS helps manipulate, retrieve and display large volumes of spatial data [23] along with efficient compilation and evaluation of the already existing data.

Although many investigations have been undertaken to integrate catchment and water management policy goals with surface and sub-surface losses of $\mathrm{N}$ and other agrochemicals (pesticides and insecticides) from watersheds under unique LU/LC conditions [24-26], studies of these losses from mixed type watersheds in order to formulate management plans are limited. Therefore, the objective of this study was to simulate runoff, sediment transport, nitrate nitrogen $\left(\mathrm{NO}_{3}-\mathrm{N}\right)$, ammonium nitrogen $\left(\mathrm{NH}_{4}-\mathrm{N}\right)$, and water soluble phosphorous (P) using the SWAT model and then apply the calibrated model to estimate the losses of $\mathrm{NO}_{3}-\mathrm{N}, \mathrm{NH}_{4}-\mathrm{N}$, water soluble $\mathrm{P}$, organic $\mathrm{N}$ and organic $\mathrm{P}$ as NPS pollutants to the downstream water resources. The model output may be utilized in the formulation of management strategies for reducing the losses as well as maintaining NPS pollution-free water resources.

\section{Study Area}

This study was carried out in a small watershed named Banha shown in Figure 1. The watershed, situated in the sub-humid subtropical region of northern India, is 1695 hectares in area, and is part of the Damodar Valley Corporation (DVC) Command, Hazaribagh, Jharkhand. About $50 \%$ of the watershed area is under shrubs and forest, $10 \%$ under barren land and the remainder under crop cultivation. The residential area of the watershed comprises about 20 hectares with individual cattle andpoultry farms. The elevation of the watershed varies from $398 \mathrm{~m}$ to $440 \mathrm{~m}$ above the mean sea level. The highest elevated area, about $25 \%$ of the watershed, is rocky

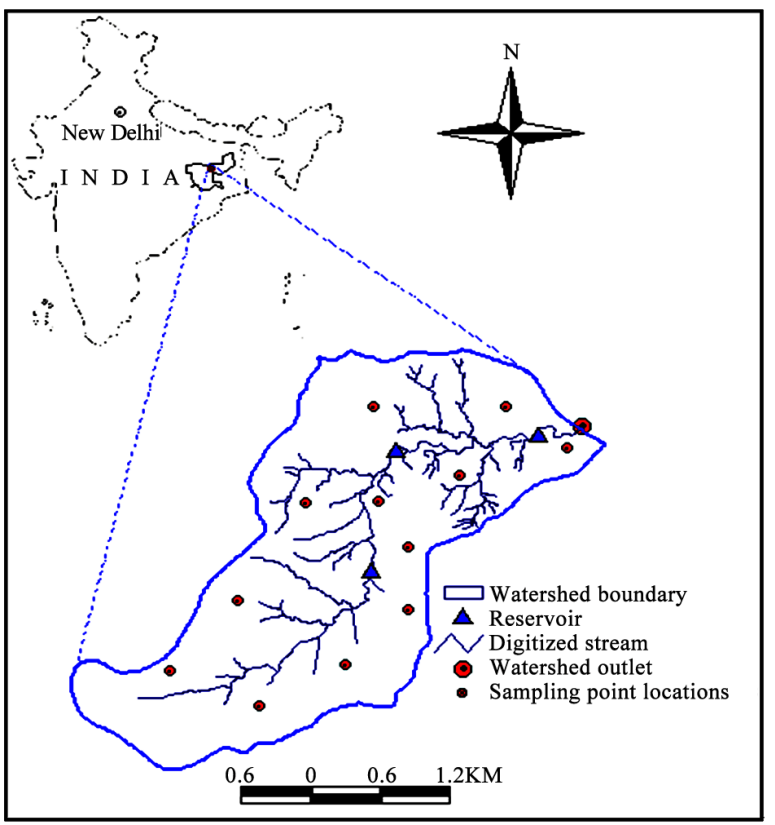

Figure 1. Banha Watershed of DVC Command, Hazaribagh, Jharkhand, India, showing sampling point locations, digitized stream, and the watershed outlet.

and covered by forest, while the rest $75 \%$ is a sloping landscape with soil depth up to $100 \mathrm{~cm}$ and includes forest, cultivated and barren lands. The slope of the area ranges from 1 to $18 \%$ with an average slope of $1.9 \%$. The average annual rainfall of the area is $1200 \mathrm{~mm}$ of which more than $80 \%$ occurs during the monsoon months of June to October and the rest falling in the winter months of December to January. The daily temperature ranges from a maximum of $42.5^{\circ} \mathrm{C}\left(1^{\text {st }}\right.$ May, 1999) to a minimum of $2.5^{\circ} \mathrm{C}\left(18^{\text {th }}\right.$ January, 1999). The daily mean relative humidity varies from a minimum of $21.72 \%$ in the month of April to a maximum of $90.36 \%$ in the month of September. The overall climate of the area is classified as sub-humid sub-tropical. The soils of the watershed vary texturally from loamy sand to loam with sandy loam as the common texture. Texturally the soils are uniform with depth. The overall soils of the watershed are neutral to slightly acidic with medium orga- nic matter and low salt content. The bulk density of the soils varies around $1.5 \mathrm{~g} / \mathrm{cc}$, with moderately low saturated hydraulic conductivity ranging from 9.7 to $16.8 \mathrm{~cm} /$ day.

The land use/land cover of the area during monsoon season mainly comprises the rice crop, although black gram, maize, soybean and vegetables are also grown on some upland patches. The forested area consists of a mixed forest of mainly sal (Shorea robusta), mahua (Madhuca indica), kend (Diospyros melanoxylon) and palas (Butea frondosa) trees. In the area there is no source of factory effluent or point sources of pollution, except the rural effluent from individual houses. Chemical fertilizers and farm yard manure (FYM) are generally used 
in crop cultivation practices. Therefore, the causes of possible NPS pollution from the area are fertilizers, individual housing effluent and forest residues.

\section{Swat Model Description}

The physically based continuous time Soil and Water Assessment Tool (SWAT), developed by USDA-ARS, was used to estimate the hydrological behavior and $\mathrm{N}$ and $\mathrm{P}$ yields from the watershed under varying soils, land use and management conditions. The studied processes of the model are described below.

\subsection{Hydrology}

In the model, hydrologic cycle is simulated based on the water balance equation. Surface runoff volume is estimated from daily rainfall using the SCS curve number technique [27] given as below:

$$
\begin{array}{ll}
Q=\frac{(R-0.2 s)^{2}}{(R+0.8 s)} & R>0.2 s \\
Q=0 & R \leq 0.2 s
\end{array}
$$

where $Q$ is the daily surface runoff ( $\mathrm{mm}), R$ is the daily rainfall $(\mathrm{mm})$ and $s$ is a retention parameter $(\mathrm{mm})$, which is related to the Curve Number $(\mathrm{CN})$ and given as:

$$
s=254\left(\frac{100}{C N}-1\right)
$$

The sediment yield from each sub-watershed is computed using the Modified Universal Soil Loss Equation (MUSLE) as

$$
Y=11.8\left(V . q_{p}\right)^{0.56} . \text { K.C.PE.LS }
$$

where $Y$ is the sediment yield from the sub-basin at time $\mathrm{t}$, $V$ is the surface runoff volume for sub-basin in $m^{3}, q_{p}$ is the peak flow rate for sub-basin in $\mathrm{m}^{3} / \mathrm{s}, K$ is the soil erodibility factor, $C$ is the crop management factor, $P E$ is the erosion control practice factor, and $L S$ is the slope length and steepness factor. MUSLE uses the amount of runoff to simulate erosion and sediment yield.

\subsection{Nutrients}

SWAT uses the modified EPIC model to compute nutrient yield and cycling from the sub-watersheds [28] as discussed below.

\subsubsection{Nitrate}

The amount of $\mathrm{NO}_{3}-\mathrm{N}$ contained in runoff, lateral flow and percolation are estimated as the product of the volume of water and concentration. The amount of $\mathrm{NO}_{3}-\mathrm{N}$ in runoff is estimated for each sub-watershed by considering the top $10 \mathrm{~mm}$ soil layer only and is given as

$$
V_{\mathrm{NO}_{3}}=(Q T)\left(C_{\mathrm{NO}_{3}}\right)
$$

where $V_{N_{3}}$ is the amount $\mathrm{NO}_{3}-\mathrm{N}$ lost from the first layer, $Q T$ is the total water lost from the first layer in $\mathrm{mm}$, and $C_{N_{3}}$ is the concentration of $\mathrm{NO}_{3}-\mathrm{N}$ in the first layer. Leaching and lateral subsurface flows in lower layers are estimated with the same approach used in the upper layer, except that surface runoff is not considered.

The loss of organic nitrogen along with the sediment transport is estimated using a modified loading function $[29,30]$ that is applicable to individual runoff events. The loading function estimates the daily organic $\mathrm{N}$ runoff loss based on the concentration of organic $\mathrm{N}$ in the top soil layer, the sediment yield, and enrichment ratio as

$$
Y N O=0.001(Y)(C O N)(E R)
$$

where $Y O N$ is the organic $N$ runoff loss at the outlet (kg/ha), CON is the concentration of organic $N$ in the top soil layer $(\mathrm{g} / \mathrm{t}), Y$ is the sediment yield (t/ha), and $E R$ is the enrichment ratio [31] and given as

$$
E R=X_{1} C_{a}^{X}
$$

where $C_{a}$ is the sediment concentration $\left(\mathrm{g} / \mathrm{m}^{3}\right)$, and $\mathrm{X}_{1}$ and $X_{2}$ are parameters set by the upper and lower limits. When the enrichment ratio approaches 1.0, the sediment concentration would be extremely high and vice versa.

\subsubsection{Phosphorous}

$\mathrm{P}$ is mostly associated with sediment and the soluble $\mathrm{P}$ runoff in SWAT is expressed as

$$
Y S P=\frac{0.01\left(C_{L P P}\right)(Q)}{k_{d}}
$$

where $Y S P$ is the soluble $\mathrm{P}(\mathrm{kg} / \mathrm{ha})$ lost in runoff volume $Q(\mathrm{~mm}), C_{L P P}$ is the concentration of soluble $\mathrm{P}$ in the soil layer $(\mathrm{g} / \mathrm{t})$, and $k_{d}$ is the $\mathrm{P}$ concentration in the sediment divided by that of the water $\left(\mathrm{m}^{3} / \mathrm{t}\right) . C_{L P P}$ is constant for the whole simulation and initially input to the model.

The sediment-associated $\mathrm{P}$ is simulated with a loading function as

$$
Y P=0.01(Y)\left(C_{p}\right)(E R)
$$

where $Y P$ is the sediment-associated $\mathrm{P}$ loss in runoff $(\mathrm{kg} / \mathrm{ha}), C_{p}$ is the concentration of $\mathrm{P}$ in the topsoil layer $(\mathrm{g} / \mathrm{t})$, and $E R$ is the enrichment ratio.

The model performs simultaneous computations on each sub-watershed and routes water, sediment, and nutrients through reaches and finally sums as loadings from the watershed.

\section{Data Collection and Model Parameter Estimation}

Daily time series of measured data on rainfall, temperature (maximum and minimum) precipitation, runoff and 
sediment transport from 1991 to 2001 were collected, processed and used to run the model for this study. The $\mathrm{NO}_{3}-\mathrm{N}, \mathrm{NH}_{4}-\mathrm{N}$ and water soluble $\mathrm{P}$ concentrations as NPS pollution data were monitored and measured at the watershed outlet during monsoon months of 2000 and 2001. Stream water samples were collected at the watershed outlet on selected dates during June to September in both the years and the runoff-associated $\mathrm{NO}_{3}-\mathrm{N}, \mathrm{NH}_{4}-\mathrm{N}$ and soluble $\mathrm{P}$ concentrations were measured at the Agricultural and Food Engineering Department, Indian Institute of Technology, Kharagpur, India, with the aid of Ion analyzers and standard methods.

Data on topography, soil type, texture, existing land use, land cover, water resources, drainage patterns of the watershed obtained from field measurement, topographic maps and remotely sensed imagery were stored in the ArcInfo GIS tool and used to generate inputs for the hydrologic and water quality model-SWAT. Physical and chemical properties of surface and sub-surface soil layers (up to $100 \mathrm{~cm}$ depth) were measured at 12 locations, well distributed over the watershed (Figure 1). The watershed was delineated using the Survey of India topographic sheets and after establishing a digitized contour coverage, a $30 \mathrm{~m} \times 30 \mathrm{~m}$ DEM was generated for estimating slope, drainage pattern, and aspect of the watershed. The watershed was sub-divided into 5 nested sub-watersheds based on drainage channels and land use/land cover (Figure 2). The Satellite imagery (IRS-1D, $15^{\text {th }}$ December, 2000) was classified to get the information on the extent of watershed land use/land cover. The land use/land cover of the watershed was classified in 9 categories: low land paddy (rice), upland crops, shallow water body, deep water body, growing forest (new plantation), degraded forest, dense forest, fallow land and eroded land, as shown in Figure 3. The sub-watershed wise summary showing its mixed nature is presented in Table 1. After the classification of imagery, the sub- watershed wise statistics were generated and used for estimating model input parameters.

The SWAT model was calibrated using daily stream flow and sediment yield measured at the watershed outlet for months of June to September, 2000, as the primary concern was to estimate the NPS pollutant loads during the monsoon season. The calibrated model was

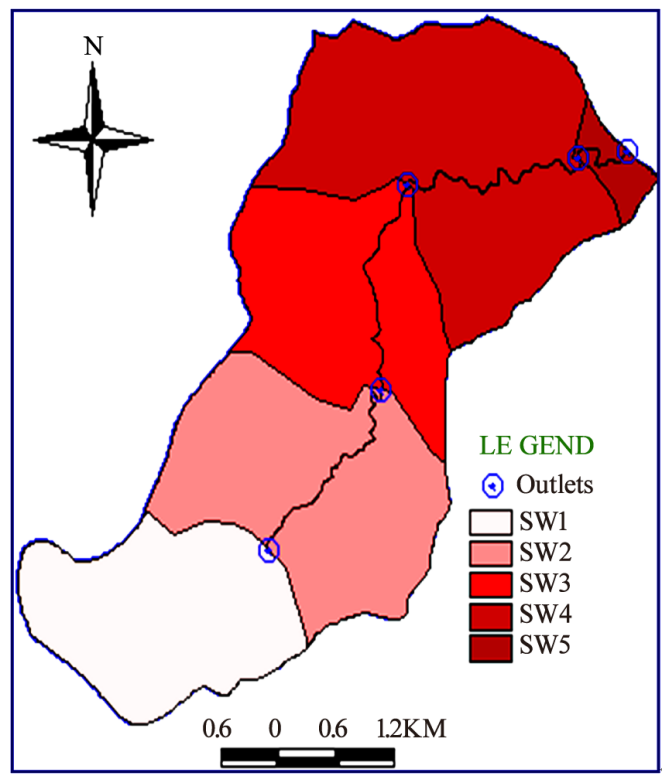

Figure 2. Sub-watershed map of Banha watershed.

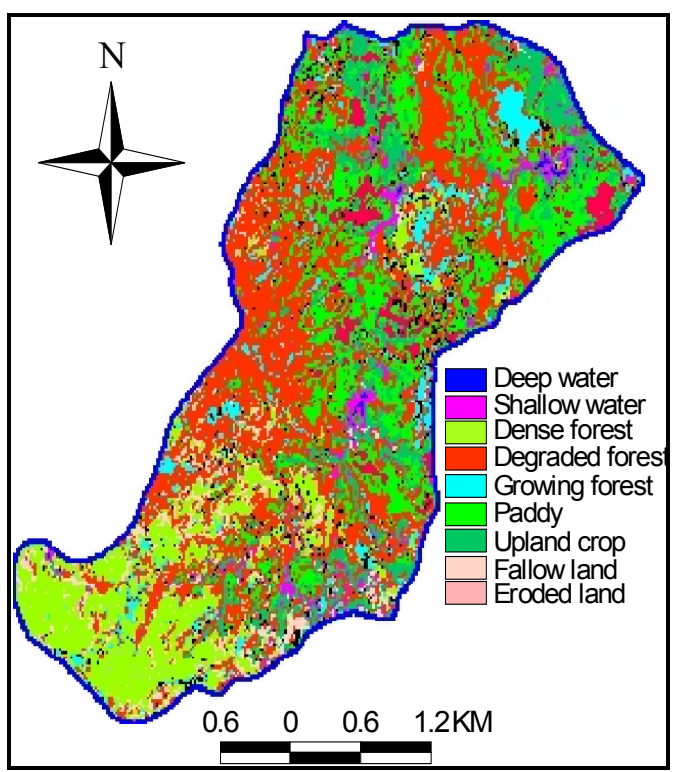

Figure 3. Land use/land cover map of Banha Watershed for the year 2000.

Table 1. Sub-watershed wise statistics of land use land cover of Banha watershed.

\begin{tabular}{|c|c|c|c|c|c|c|c|}
\hline \multirow{2}{*}{$\mathbf{L U} / \mathbf{L C}$} & \multicolumn{5}{|c|}{ Area under different LU/LC (ha) } & \multirow{2}{*}{ Total } & \multirow{2}{*}{$\begin{array}{c}\% \\
\text { Area }\end{array}$} \\
\hline & SWS1 & SWS2 & SWS3 & SWS4 & SWS5 & & \\
\hline Forest & 224.95 & 251.13 & 126.90 & 255.41 & 19.50 & 877.89 & 51.79 \\
\hline Paddy-cultivation & 76.74 & 111.32 & 139.36 & 194.05 & 12.37 & 533.84 & 31.49 \\
\hline Water bodies & 6.24 & 16.85 & 32.71 & 48.46 & 3.97 & 108.23 & 6.39 \\
\hline Fallow land & 10.12 & 21.56 & 13.78 & 18.86 & 3.11 & 67.44 & 3.98 \\
\hline Eroded land & 18.11 & 24.92 & 17.89 & 39.10 & 2.11 & 102.13 & 6.03 \\
\hline Residential Area & 1.15 & 1.33 & 1.05 & 1.83 & 0.14 & 5.50 & 0.32 \\
\hline Total area (ha) & 337.31 & 427.11 & 331.68 & 557.72 & 41.20 & 1695.02 & 100.00 \\
\hline
\end{tabular}


tested to simulate the concentrations of $\mathrm{NO}_{3}-\mathrm{N}, \mathrm{NH}_{4}-\mathrm{N}$, and water soluble $\mathrm{P}$ in stream flow, and the model results were compared with measured values. The properly calibrated model was then used to estimate the loads of NPS pollutants and runoff from the watershed.

\section{Performance Evaluation of Model Simulations}

The values of daily runoff and associated NPS pollutant concentrations simulated by SWAT were compared with observed values by plotting hydrographs and scaterograms. Particular attention was given to the magnitude of event and its closeness to the measured value. For quantitative assessment, Student's t-test, Coefficient of determination $\left(R^{2}\right)$, Nash-Sutcliffe Simulation Efficiency $\left(E_{N S}\right)$, Root Mean Square Error, (RMSE) and Percentage Deviation $\left(D_{v}\right)$ test between measured and simulated values were calculated.

Comparison of significant differences between the mean values of observed and model simulated values was done using Student's t-test as

$$
t_{c}=\frac{\left(S_{A v g}-O_{A v g}\right) N^{0.5}}{\left(S_{s}^{2}+O_{s}^{2}\right) 0.5}
$$

where $S_{A v g}$ and $O_{A v g}$ are the averages of simulated and observed values, and $S_{S}$ and $O_{S}$ are the standard deviations of simulated and observed values, respectively. If the calculated value of student's t-test $\left(t_{c}\right)$ was less than that of the t-tabulated value with $N-1$ degree of freedom and $5 \%$ level of significance (i.e., $\propto=0.05$ for two tailed ' $t$ '-test), then the difference between the means was not significant at the $5 \%$ significant level.

The coefficient of determination $\left(R^{2}\right)$ describes the proportion of the total variance in the observed data that can be explained by the model. It ranges from 0.0 to 1.0 , with higher values indicating better agreement, and is given as

$$
R^{2}=\left\{\frac{\sum_{i=1}^{N}\left(O_{i}-O_{A v g}\right)\left(S_{i}-S_{A v g}\right)}{\left(\sum_{i=1}^{N}\left(O_{i}-O_{A v g}\right)^{2}\right)^{0.5}\left(\sum_{i=1}^{N}\left(S_{i}-S_{A v g}\right)^{2}\right)^{0.5}}\right\}
$$

where $O_{i}$ is the $i^{\text {th }}$ observed value, $O_{\text {Avg }}$ is the mean of the observed values, $S_{i}$ is the $i^{\text {th }}$ simulated value, $S_{A v g}$ is the mean of model simulated values, and $N$ is the total number of events.

Simulation efficiency $\left(E_{N S}\right)$ or modelling efficiency [32] expresses the fraction of the measured streamflow variance that was reproduced by the model. $E_{N S}$ is expressed as

$$
E_{N S}=1-\frac{\sum_{i=1}^{N}\left(S_{i}-O_{i}\right)^{2}}{\sum_{i=1}^{N}\left(O_{i}-O_{\text {Avg }}\right)^{2}}
$$

The $E_{N S}$ value varies from 0 to 1 , with 1 indicating a perfect fit.

RMSE is estimated as:

$$
R M S E=\sqrt{\frac{1}{N} \sum_{i=1}^{N}\left(S_{i}-O_{i}\right)^{2}}
$$

The percentage deviation $\left(D_{V}\right)$ is a measure of the differences in observed and simulated values for the particular period of analysis and is given as

$$
D_{v}(\%)=\frac{V-V^{\prime}}{V} \times 100
$$

where $V$ is the measured runoff volume and $V^{\prime}$ is the model simulated runoff volume. The smaller the value of $D_{v}$, better the model result. For a perfect model, $D_{v}$ would be equal to zero.

The prediction performance and acceptable limits were determined based on the criteria suggested by Bingner et al. [33]. The underprediction or overprediction limits were determined for model simulation within or equal to $\pm 20 \%$ of measured and considered as acceptable levels of simulation accuracy. The underprediction or overprediction in terms of the percent deviation, $\pm 10 \%$ as low (slight), \pm 10 to $20 \%$ as moderate, \pm 20 to $30 \%$ as severe and greater than $\pm 30 \%$ as very severe, were considered.

\section{Results and Discussion}

\subsection{Hydrologic Calibration}

Calibration of the SWAT model was done using measured data for the monsoon months of June to September of 2000. The time series of measured and model simulated daily stream flow and sediment yield from the watershed were compared, as shown in Figures $\mathbf{4}$ and 5. It is apparent from Figure 4(a) that simulated runoff followed, in general, a trend similar to that of measured runoff. The magnitude and temporal variation of simulated runoff showed a good response to rainfall distribution and a close match with measured values, except that a few peaks marginally deviated from measured daily runoff peaks. The differences between measured and simulated runoff values can be ascribed to topographic and morphological heterogeneity of the watershed affecting the watershed runoff response. Comparison showed that most of the compared points were evenly distributed around the 1:1 line, except for a few events of higher and lower magnitudes. 
Comparison of the time series of measured and simulated daily sediment yield is shown in Figure 5. The model simulated daily sediment yields were a little higher than measured values for high rainfall events but for medium rainfall events the simulated values deviated less from the measured sediment yield. This can be attributed to the model rather than rainfall characteristics. The differences can also be ascribed to the nature of rains and soil conditions over the watershed. Comparison between simulated and measured daily sediment yields, as shown in Figure 5(b), depicts that simulated sediment yield is well distributed about the 1:1 line with slight over prediction during high magnitude events.

Statistical tests (Table 2) performed on measured and

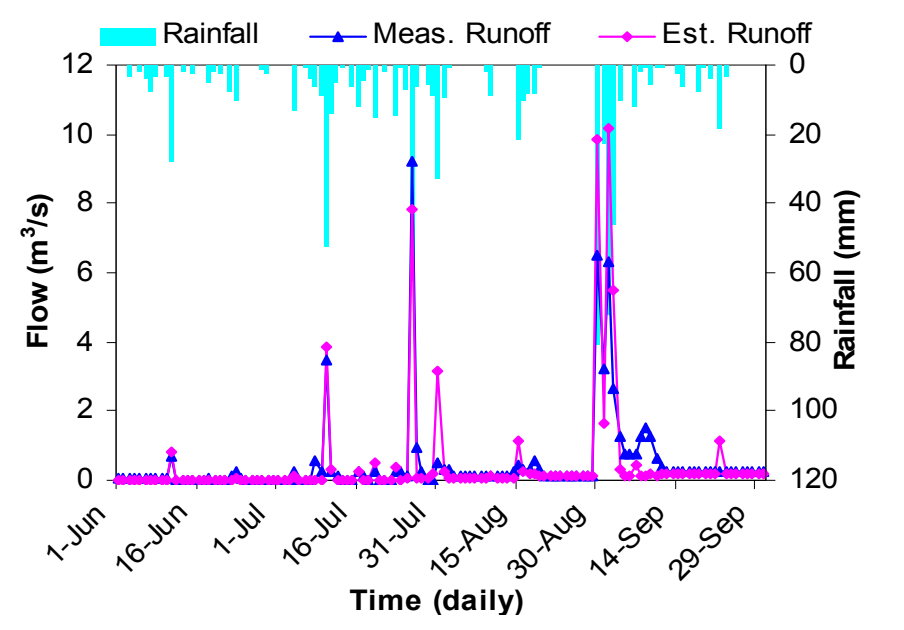

(a) simulated daily flow and sediment yield showed that the measured and simulated mean flow and sediment yield were not significantly different at the $95 \%$ confidence level during the hydrologic calibration of the model as the calculated student's t-test values were lower than their critical limits. The values of $R^{2}(0.83$ and 0.80$)$ and $E_{N S}(0.70$ and 0.73$)$, respectively, for daily flow and sediment yield also indicated better agreement between measured and simulated values. The respective values of $\operatorname{RMSE}\left(0.68 \mathrm{~m}^{3} / \mathrm{s}\right.$ and $\left.7.42 \mathrm{~g} / \mathrm{L}\right)$ and $D_{v}(3.58$ and -6.65$)$ for daily flow and sediment yield showed that the model slightly under-predicted daily flow and over-predicted daily sediment yield but well within acceptable limits of accuracy during the simulation period.

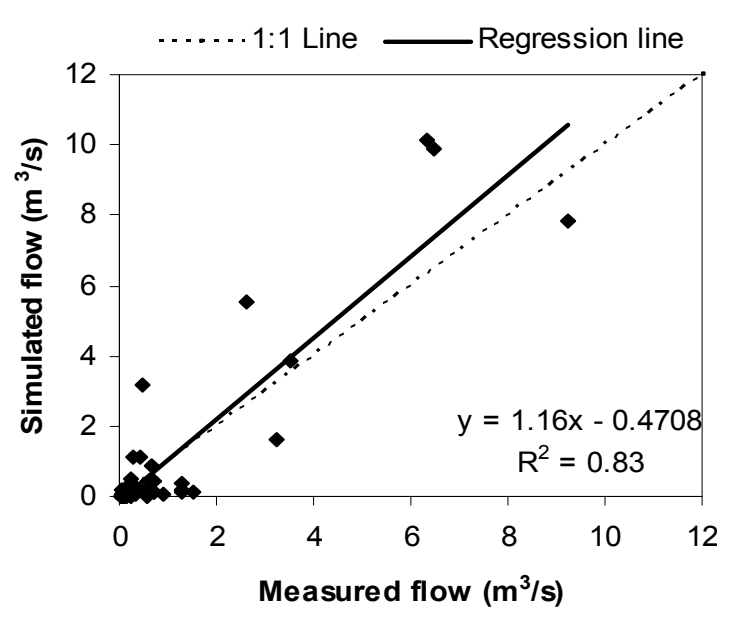

(b)

Figure 4. (a) Measured and SWAT simulated daily flow; (b) scatergram plot used for hydrologic calibration of the model.

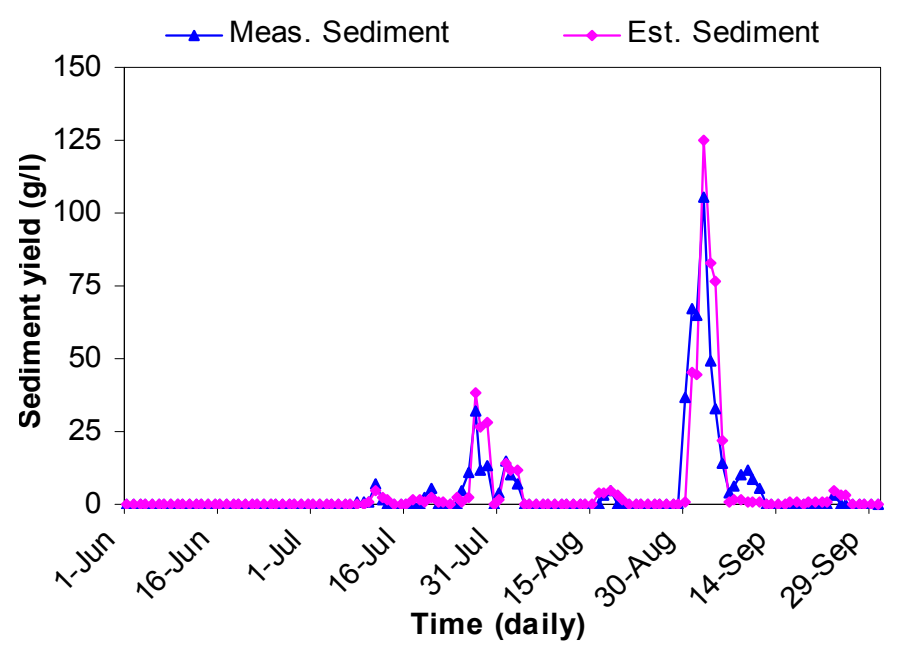

(a)

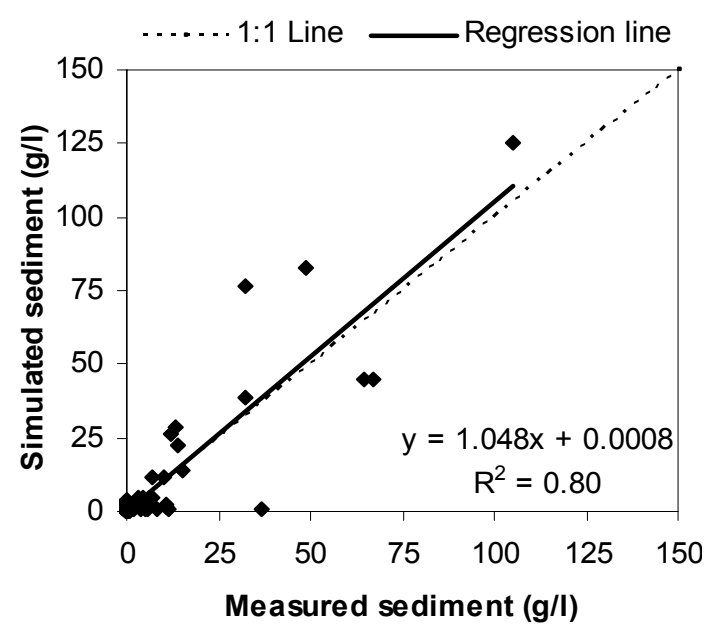

(b)

Figure 5. (a) Measured and SWAT simulated daily sediment yield; (b) scatergram plot used for hydrologic calibration of the model. 
From the graphical as well as statistical comparisons it can be inferred that the model calibrated parameters for the studied watershed represented quite realistically the nature and behavior of the watershed. The marginal differences can be the results from the inaccuracies involved in the model presentation of the subtle differences in channel, soil and sub-surface water properties [34]. Hence, the SWAT model can be used for the simulation of the studied watershed.

\subsection{Simulation Validation of Model for NPS Pollution}

The calibrated SWAT model was used to simulate the NPS water pollution due to the losses of nutrient from the watershed during June to September, 2000, and simulate the same during monsoon months of June to October of 2001. Measured concentrations of $\mathrm{NO}_{3}-\mathrm{N}, \mathrm{NH}_{4}-\mathrm{N}$ and soluble $\mathrm{P}$ in the surface runoff at the watershed outlet in 2000 and 2001 were used for the validation of model simulations. Measured and simulated $\mathrm{NO}_{3}-\mathrm{N}, \mathrm{NH}_{4}-\mathrm{N}$ and soluble $\mathrm{P}$ concentrations at the watershed outlet for the monsoon seasons of 2000 and 2001 are presented, respectively, in Figure 6 for $\mathrm{NO}_{3}-\mathrm{N}$, Figure 7 for $\mathrm{NH}_{4}-\mathrm{N}$, and Figure 8 for soluble $\mathrm{P}$.

Figure 6 shows that the NPS $\mathrm{NO}_{3}-\mathrm{N}$ loading is generally closely predicted by the model for all events, except for initial events in 2000. However, statistical comparisons between measured and simulated $\mathrm{NO}_{3}-\mathrm{N}$ (Table 3) indicate a close agreement at the $95 \%$ level of confidence

Table 2. Statistical test results of the measured and SWAT simulated daily runoff and sediment yield.

\begin{tabular}{lcc}
\hline \multicolumn{1}{c}{ Statistical parameters } & Stream flow & Sediment yield \\
\hline t-calculated & 0.09 & -0.15 \\
t-critical (two tail) & 1.97 & 1.97 \\
Coefficient of determination $\left(\mathrm{R}^{2}\right)$ & 0.83 & 0.80 \\
Nash-Sutcliffe simulation efficiency ( $\left.\mathrm{E}_{\mathrm{NS}}\right)$ & 0.70 & 0.73 \\
Root mean square error, RMSE & 0.68 & 7.42 \\
Deviation, Dv (\%) & 3.58 & -6.65 \\
\hline
\end{tabular}

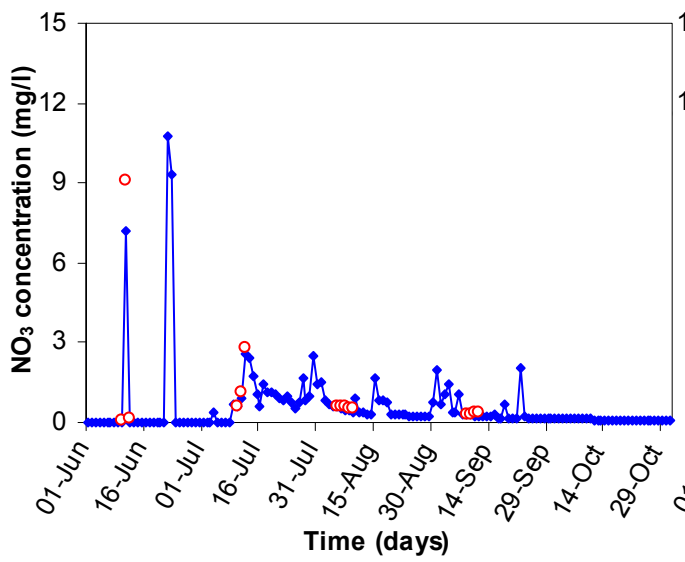

(a)

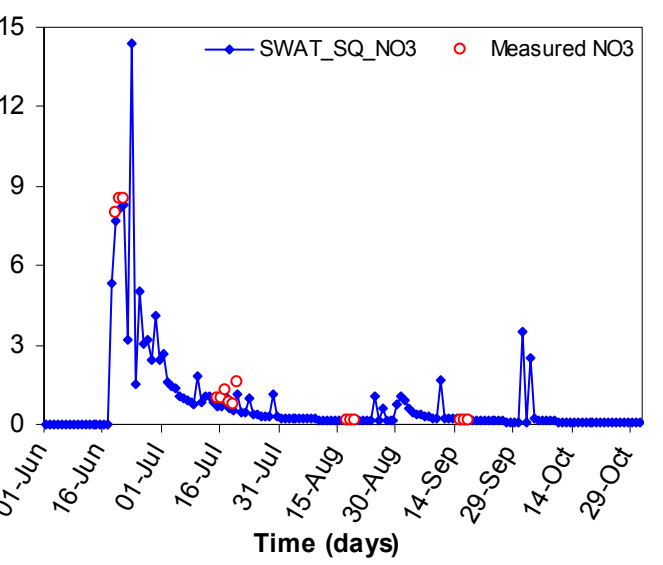

(b)

Figure 6. Measured and SWAT simulated NPS-NO$-\mathrm{N}_{3}-\mathrm{N}$ concentration at the watershed outlet in 2000 (a) and in 2001 (b).

Table 3. Statistical test results of measured and SWAT simulated $\mathrm{NO}_{3}-\mathrm{N}, \mathrm{NH}_{4}-\mathrm{N}$ and $\mathrm{P}$ concentration in runoff of 2000 and 2001.

\begin{tabular}{ccccccc}
\hline \multirow{2}{*}{$\begin{array}{c}\text { Statistical } \\
\text { parameters }\end{array}$} & \multicolumn{2}{c}{$\mathbf{N O}_{3}-\mathbf{N}$} & \multicolumn{2}{c}{$\mathbf{N H}_{4}-\mathbf{N}$} & \multicolumn{2}{c}{ Soluble P } \\
\cline { 2 - 6 } & $\mathbf{2 0 0 0}$ & $\mathbf{2 0 0 1}$ & $\mathbf{2 0 0 0}$ & $\mathbf{2 0 0 1}$ & $\mathbf{2 0 0 0}$ & $\mathbf{2 0 0 1}$ \\
\hline t-calculated & 0.29 & 0.15 & 0.20 & 0.20 & 0.35 & 0.61 \\
t-critical (two tail) & 2.05 & 2.06 & 2.05 & 2.06 & 2.06 & 2.08 \\
$\mathrm{R}^{2}$ & 0.99 & 0.99 & 0.99 & 0.90 & 0.98 & 0.90 \\
$\mathrm{E}_{\mathrm{NS}}$ & 0.95 & 0.99 & 0.98 & 0.88 & 0.89 & 0.83 \\
$\mathrm{RMSE}$ & 1.08 & 1.13 & 1.15 & 1.13 & 1.13 & 1.10 \\
Dv (\%) & 18.14 & 7.97 & 14.79 & 11.08 & 24.45 & 33.48 \\
\hline
\end{tabular}


as t-calculated (0.29 and 0.15$)$ was less than t-critical (2.05 and 2.06) for both 2000 and 2001. An acceptable agreement between measured and simulated $\mathrm{NO}_{3}-\mathrm{N}$ is also indicated by the values of coefficients of determination (0.99 and 0.99) and Nash-Sutcliffe simulation efficiencies $(0.95$ and 0.99$)$ in both years. The root mean square errors for 2000 and 2001 were estimated as 1.08 and $1.13 \mathrm{mg} / \mathrm{l}$, respectively. The percent deviation of 18.14 and 7.97 for 2000 and 2001, respectively, indicated that the model under-predicted $\mathrm{NO}_{3}-\mathrm{N}$, particularly in 2000. Although the model under-predicted the $\mathrm{NO}_{3}-\mathrm{N}$ concentration, considering the statistical agreement the model predictions were acceptable.

Comparison of measured and simulated concentrations of $\mathrm{NH}_{4}-\mathrm{N}$ for 2000 and 2001, shown, respectively, in Figure 7(a) and (b), revealed that the simulated values of $\mathrm{NH}_{4}-\mathrm{N}$ were in close agreement with measured values. The results of statistical tests indicated that the differences of means of measured and simulated $\mathrm{NH}_{4}-\mathrm{N}$ were not significant at the $95 \%$ confidence level, since t-calculated ( 0.20 and 0.20$)$ was less than t-critical $(2.05$ and 2.06). The values of coefficients of determination
(0.99 and 0.90) and the Nash-Sutcliffe simulation efficiencies (0.98 and 0.88) indicated an acceptable performance of the model. The root mean square error values for 2000 and 2001 were estimated as 1.15 and $1.13 \mu \mathrm{g} / \mathrm{L}$, respectively. The values of percent deviation of 14.79 for 2000 and 11.08 for 2001 indicated that the model performance was good, although the $\mathrm{NH}_{4}-\mathrm{N}$ concentration was under-predicted. However, overall comparison of statistical tests revealed that the model predictions of $\mathrm{NH}_{4}-\mathrm{N}$, though lower than measured, but still within the acceptable level, may be used for the analysis of watershed behavior.

Comparison between the measured and simulated values of soluble $\mathrm{P}$ for the selected observation dates of 2000 and 2001 shown in Figure 8(a) and (b), respectiveely, revealed that the simulated values of soluble $\mathrm{P}$ were marginally under predicted by the model at least for the observation dates. The statistical tests performed on the measured and simulated soluble $\mathrm{P}$ showed that the differrences were not significant at the $95 \%$ confidence level, since t-calculated (0.35 for 2000 and 0.61 for 2001) values were less than the t-critical (2.06 for 2000 and

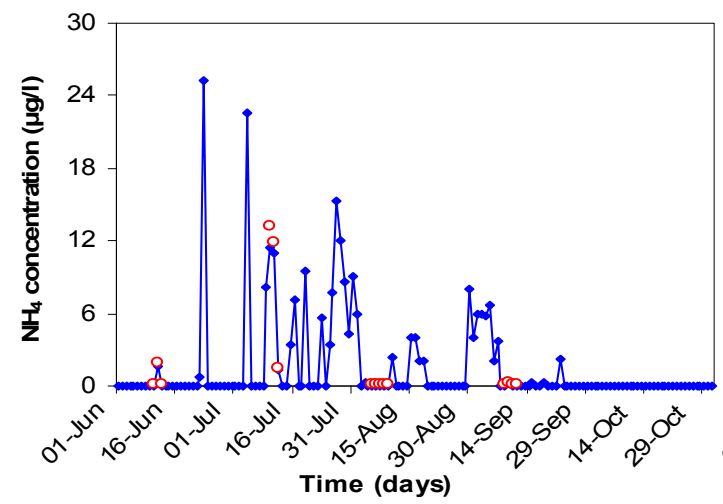

(a)

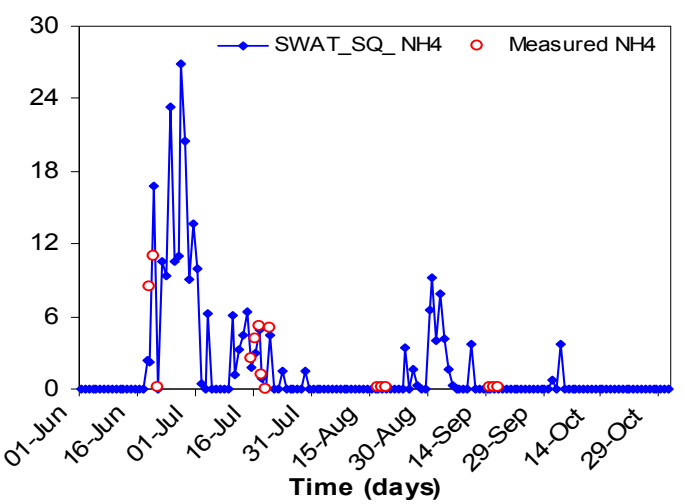

(b)

Figure 7. Measured and SWAT simulated NPS- $\mathrm{NH}_{4}-\mathrm{N}$ concentration at the watershed outlet in 2000 (a) and in 2001 (b).

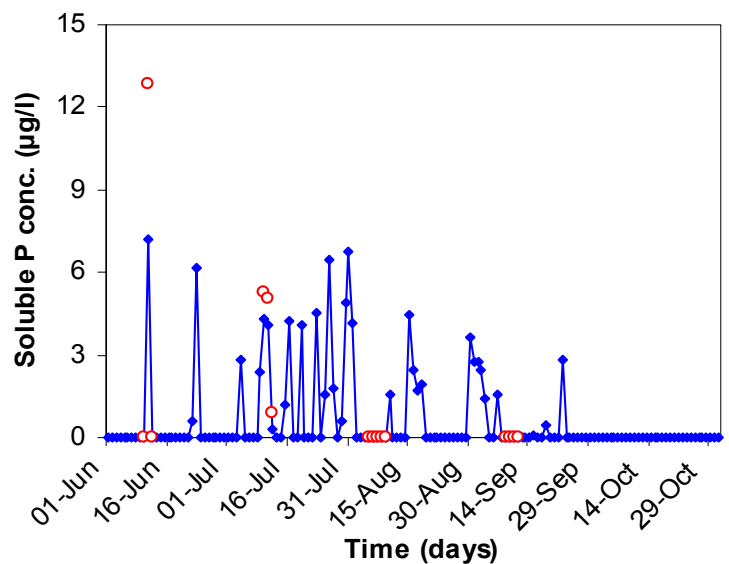

(a)

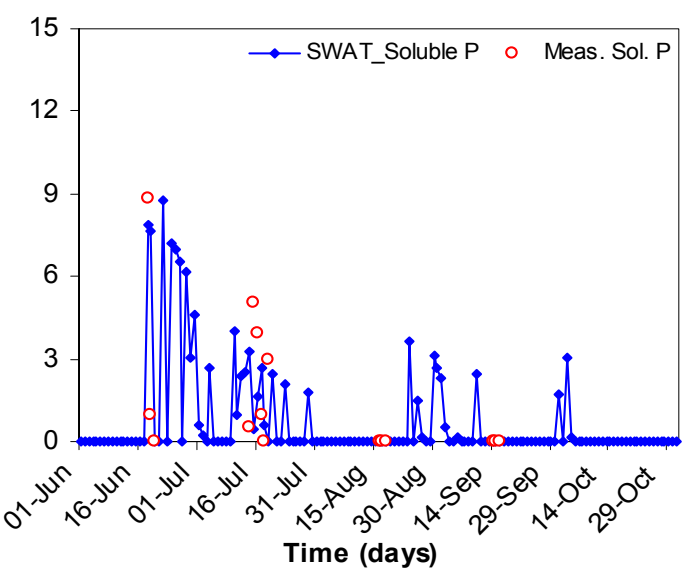

(b)

Figure 8. Measured and SWAT simulated NPS water soluble P concentration at the watershed outlet in 2000 (a) and in 2001 (b). 
2.08 for 2001) values. The values of coefficient of determination (0.98 for 2000 and 0.90 for 2001) and Nash-Sutcliffe simulation efficiencies ( 0.89 for 2000 and 0.83 for 2001) indicated a better agreement between measured and simulated values for 2000 . The root mean square errors for 2000 and 2001 were estimated as 1.13 and $1.10 \mu \mathrm{g} / \mathrm{L}$, respectively. The values of the overall deviation indicated that soluble $\mathrm{P}$ was severely under-predicted (24.45\%) in 2000 and $(33.48 \%)$ in 2001. However, the overall statistical comparison showed that the model performance was satisfactory with respect to the simulation of soluble $\mathrm{P}$. The simulation results of NPS pollutants are in conformity with the findings of other researchers [35-37].

\subsection{Estimation of NPS Pollution Load from the Watershed}

Monthly surface and sub-surface losses of $\mathrm{NO}_{3}-\mathrm{N}, \mathrm{NH}_{4}-$ $\mathrm{N}$, soluble $\mathrm{P}$, organic $\mathrm{N}$ and organic $\mathrm{P}$ on a per hectare basis as NPS pollutants loads from the watershed to the downstream water were estimated from the validated SWAT model. The results obtained are shown in Figure 9. Figures 9(a) and (b) show monthly rainfall distribution, Figures 9(c) and (d) show $\mathrm{NO}_{3}-\mathrm{N}$ and Figures 9(e) and (f) show $\mathrm{P}$ and $\mathrm{N}$ species loads from the watershed during the monsoon months of 2000 and 2001. It is apparent from Figures 9(c) and (d) that an appreciable amount of $\mathrm{NO}_{3}-\mathrm{N}$ was lost in surface runoff with the percolated water. However, nutrient losses due to the sub-surface flow were relatively low. The loss of organic $\mathrm{N}$ was also quite high compared to organic $\mathrm{P}$ and $\mathrm{NH}_{4}-\mathrm{N}$ (Figures 9(e) and (f)). The quantified nutrient loads from the watershed varied from 2.57 to $4.52 \mathrm{~kg} / \mathrm{ha}$ as $\mathrm{NO}_{3}-\mathrm{N}$ lost in surface runoff, 0.17 to $0.29 \mathrm{~kg} / \mathrm{ha}$ as $\mathrm{NO}_{3}-\mathrm{N}$ lost in sub-surface runoff, 1.73 to $3.87 \mathrm{~kg} / \mathrm{ha}$ as $\mathrm{NO}_{3}-\mathrm{N}$ lost with percolated water, 0.13 to $0.14 \mathrm{~kg} / \mathrm{ha}$ as organic-N, 0.02 $\mathrm{kg} / \mathrm{ha}$ as $\mathrm{NH}_{4}-\mathrm{N}, 0.02 \mathrm{~kg} / \mathrm{ha}$ as organic $\mathrm{P}$ and $0.01 \mathrm{~kg} / \mathrm{ha}$ as soluble $\mathrm{P}$ from the watershed as NPS pollutants during monsoon months of 2000 and 2001.

Figure 9 shows a clear variation in simulated losses of $\mathrm{N}$ and $\mathrm{P}$ for 2000 and 2001 which was due to the variation in rainfall intensity and distribution in both the years and had a high effect on transport characteristics of NPS pollutants. Because of initial small rainfall in 2000, the surface runoff loss of $\mathrm{NO}_{3}-\mathrm{N}$ was less than that in 2001 (Figures 9(c) and (d)), whereas the generation of sediment was more due to dry soil condition in 2000 , and the organic-N loss was more in the monsoon months of 2000 than that in 2001.

These per hectare losses were used to assess the total load of agro-chemicals in runoff which threaten downstream water resources as NPS pollution. These are presented as total loads in Table 4. It is clear from the table that stream water going out from the watershed contained the maximum load of $\mathrm{NO}_{3}-\mathrm{N}$ which ranged from $4356.15 \mathrm{~kg}$ in 2000 to as high as $7661.40 \mathrm{~kg}$ in 2001 . However, the watershed showed a low vulnerability to the loss of water soluble P.

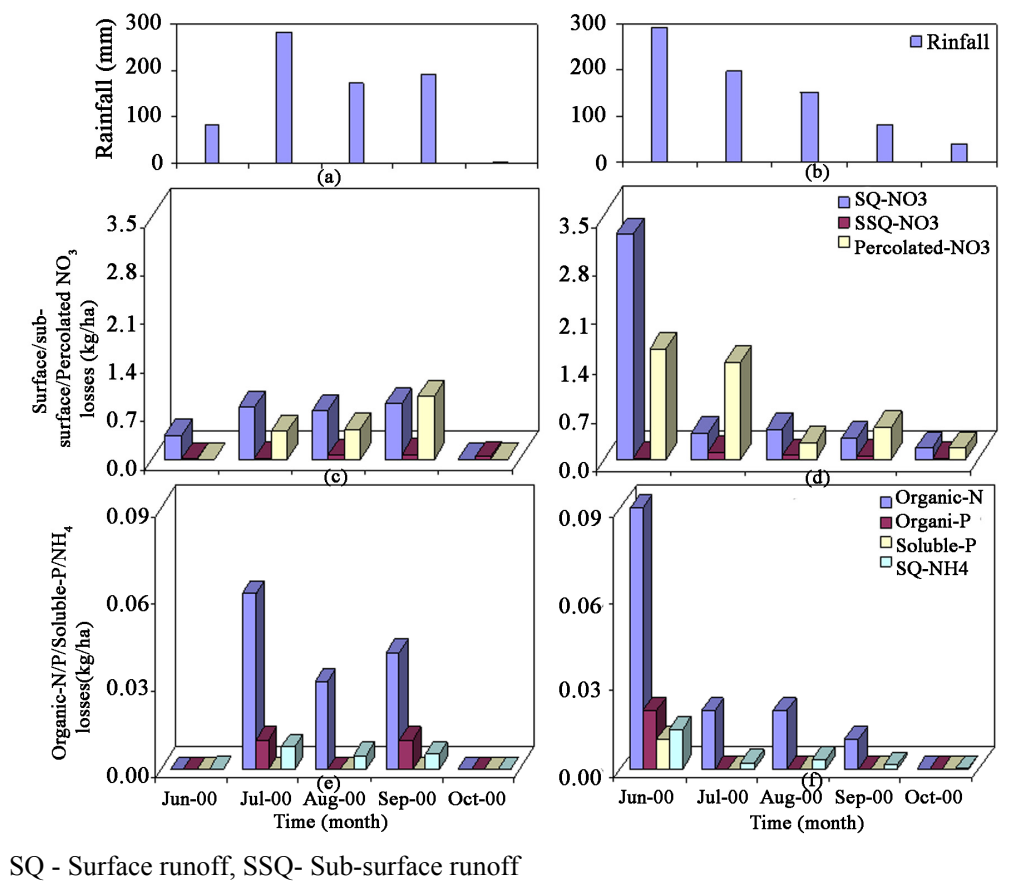

Figure 9. SWAT-simulated surface and sub-surface losses of $\mathrm{NO}_{3}-\mathrm{N}, \mathrm{NH}_{4}-\mathrm{N}$, Soluble $\mathrm{P}$, organic $\mathrm{N}$ and organic $\mathrm{P}$ from the watershed in 2000 and 2001. 
Table 4. SWAT estimated losses of $N$ and $P$ species as NPS pollutants from the watershed.

\begin{tabular}{lcc}
\hline \multicolumn{1}{c}{ Losses of $\mathbf{N}$ and P species in- } & \multicolumn{2}{c}{ Runoff loads as losses (kg) from watershed in year } \\
\cline { 2 - 3 } & $\mathbf{2 0 0 0}$ & $\mathbf{2 0 0 1}$ \\
\hline Surface runoff- $\mathrm{NO}_{3}-\mathrm{N}$ & 4356.15 & 7661.40 \\
Subsurface runoff- $\mathrm{NO}_{3}-\mathrm{N}$ & 288.15 & 491.55 \\
Percolation- $\mathrm{NO}_{3}-\mathrm{N}$ & 2932.35 & 6559.65 \\
Surface runoff- $\mathrm{NH}_{4}-\mathrm{N}$ & 30.07 & 34.24 \\
Organic- $\mathrm{N}$ & 220.35 & 237.30 \\
Organic- $\mathrm{P}$ & 33.90 & 33.90 \\
Soluble- $\mathrm{P}$ & 0.00 & 16.95 \\
\hline
\end{tabular}

\section{Conclusions}

Estimation of $\mathrm{N}$ and $\mathrm{P}$ loads from a mixed type watershed in a sub-humid subtropical region as NPS pollutants to the downstream water resources show a quite good amount of nutrient loss from the watershed. The study also reveals that these losses are highly dependent on the pattern of rainfall. During the study period 2000 and 2001, maximum seasonal loss of nutrient $\mathrm{N}$ and $\mathrm{P}$ estimated from the watershed are $8.84 \mathrm{~kg} / \mathrm{h}$ and $0.03 \mathrm{~kg} / \mathrm{ha}$, respectively, which, when viewed in terms of total nutrient loss from watershed and a possible threat to water pollution, comes about 7.6 tonnes of $\mathrm{NO}_{3}-\mathrm{N}$ in surface water and about 6.5 tonnes of $\mathrm{NO}_{3}-\mathrm{N}$ in percolated water.Since losses clearly show an effect of rainfall pattern, protection and control management strategies should be formulated accordingly before losses occur. To reduce non-point source pollutant loading the best management practices on land use, improved tillage, application of fertilizer and soil and water conservation can be adopted suitably. The overall results of the present study conclude that the estimation of NPS pollutant load from a small mixed type watershed in sub-humid subtropical region can be performed successfully with the aid of SWAT-a hydrologic-water quality model-and also applied to the NPS pollution management of water resources. Once the scenarios to manage these losses are analyzed using the SWAT model, a sustainable management practice may be formulated.

\section{References}

[1] M. Neill, "Nitrate Concentrations in River Water in the South-east of Ireland and their Relationship with Agricultural Practices," Water Science Research, Vol. 23, 1989, pp. 1339-1355.

[2] G. G. Wright, A. C. Edwards, J. G. Morrice and K. Pugh, "North East Scotland River Catchment Nitrate Loading in Relation to Agricultural Intensity," Chemistry and Ecology, Vol. 5, 1991, pp. 263-281.
[3] B. Kronvang, R. Grant, S. E. Larsen, L. M. Svendsen and P. Kristensen, "Non-point-source Nutrient Losses to the Aquatic Environment in Denmark: Impact of Agriculture," Marine Freshwater Research, Vol. 46, 1995, pp. 146-177.

[4] Z. Liu, D. E. Weller, D. L. Correll and T. E. Jordan, "Effects of Land Cover and Geology on Stream Chemistry in Watersheds of Chesapeake Bay," Journal of the American Water Resources Association, Vol. 36, No. 6, 2000, pp. 1349-1365.

[5] I. Y. Yeo, S. I. Gordon and J. M. Guldmann, "Optimizing Patterns of Land Use to Reduce Peak Runoff Flow and Nonpoint Source Pollution with an Integrated Hydrological and Land-use Model," Journal of Earth Interactions, Vol. 8, No. 6, 2004, pp. 1-20.

[6] O. Nagafuchi, T. Inoue and S. Ebise, "Runoff Pattern of Pesticides from Paddy Fields in the Catchment Area of Rikimaru Reservoirs, Japan," Water Science and Technology, Vol. 30, No. 7, 1994, pp. 137-144.

[7] O. Kawara, K. Hirayma and T. Kunimatsu, "A Study on Pollutant Loads from the Forest and Rice Paddy Fields," Water Science and Technology, Vol. 33, No. 4-5, 1996, pp. 159-165.

[8] J. Kammerbauer and J. Moncada, "Pesticide Residue Assessment in Three Selected Agricultural Production Systems in the Choluteca River Basin of Honduras," Environmental Pollution, Vol. 103, No. 2-3, November 1998, pp. 171-181.

[9] H. E. Andersen, B. Kronvang and S. E. Larsen, "Agricultural Practices and Diffuse Nitrogen Pollution in Denmark: Empirical Leaching and Catchment Models," Water Science and Technology, Vol. 39, No. 12, 1999, pp. 257-264.

[10] USEPA, "Guidance Specifying Management Measures for Sources of Non-Point Pollution in Coastal Waters," United States Environmental Protection Agency, Washington, D.C., 1993.

[11] USEPA, "Chesapeake Bay: A Framework for Action," United States Environmental Protection Agency, Philadelphia, 1983.

[12] M. Borin and E. Bigon, "Abatement of $\mathrm{NO}_{3}-\mathrm{N}$ Concentration in Agricultural Waters by Narrow Buffer Strips," Environmental Pollution, Vol. 117, 2002, pp. 165-168. 
[13] G. D. Liu, W. L. Wu and J. Zhang, "Regional Differentiation of Non-Point Source Pollution of Agriculture-derived Nitrate Nitrogen in Groundwater in Northern China," Agriculture, Ecosystems and Environment, Vol. 107, 2005, pp. 211-220.

[14] J. R. Scudlark, J. A. Jennings, M. J. Roadman, K. B. Savidge and W. J. Ullman, "Atmospheric Nitrogen Inputs to the Delaware Inland Bays: The Role of Ammonia," Environmental Pollution, Vol. 135, 2005, pp. 433-443.

[15] D. K. Mondal and S. Kar, "Soil Loss of Nitrogen under Rice," Journal of Indian Society of Soil Science, Vol. 39, 1991, pp. 764-766.

[16] G. D. Agrawal, "Diffuse Agricultural Water Pollution in India," Water Science and Technology, Vol. 39, No. 3, 1999, pp. 33-47.

[17] G. D. Agrawal, S. K. Lunkad and T. Malkhed, "Diffuse Agricultural Nitrate Pollution of Groundwaters in India," Water Science and Technology, Vol. 39, No. 3, 1999, pp. 67-75.

[18] S. Kar, R. K. Malla, N. Mogilaiah and K. J. Parashram, "Modelling Fertilizer Nitrogen Transport in Rice Ecosystems," In: B. B. Jana, R.D. Banergee, B.Guterstam and J. Heeb Ed., Waste Recycling and Resource Management in the Developing World: Ecological Engineering Approach, University of Kalyani and University of Switzerland, 2000, pp. 647-656.

[19] K. A. Poiani and B. L. Bedford, "GIS-based Non-Point Source Pollution Modelling: Considerations for Wetlands," Journal of Soil and Water Conservation, Vol. 49, No. 6, 1995, pp. 613-619.

[20] M. D. Yang, C. J. Merry and R. M. Sykes, "Integration of Water Quality Modelling, Remote Sensing, and GIS," Journal of American Water Resources Association, Vol. 35, No. 2, 1999, pp. 253-263.

[21] M. Noguchi, T. Hiwatashi, Y. Mizuno and M. Minematsu, "Pollutant Runoff from Non-point Sources and its Estimation by Runoff Models," Water Science and Technology, Vol. 46, No. 11-12, 2002, pp. 407-412.

[22] F. Morari, E. Lugato and M. Borin, "An Integrated Nonpoint Source Model-GIS System for Selecting Criteria of Best Management Practices in the Po Valley, North Italy," Agriculture, Ecosystems and Environment, Vol. 102, No. 3, 2004, pp. 247-262.

[23] R. Nielsen, T. Sobecki, R. Bigler and D. Lytle, "Application of Soil Survey Attribute Data to GIS Pollution Assessment Models," In: D. L. Corwin and K. Loague Ed., Applications of GIS to the Modeling of Non-Point Source Pollutants in the Vadose Zone, Soil Science Society of America Special Publication, Madison, No. 48, 1996, pp. 175-183.

[24] Yong Li and J. Zhang, "Agricultural Diffuse Pollution from Fertilizers and Pesticides in China," Water Science and Technology, Vol. 39, No. 3, 1999, pp. 25-32.

[25] V. de Vlaming, C. DiGiorgi, S. Fong, L. A. Deanovic, M. D. Carpio-Obeso, J. L. Miller, M. J. Miller and N. J.
Richard, "Irrigation Runoff Insecticide Pollution of Rivers in the Imperial Valley, California (USA)," Environmental Pollution, Vol. 132, No. 2, 2004, pp. 213-229.

[26] A. Kull, E. Uuemaa, V. Kuusemets and Ü. Mander, "Modelling of Excess Nitrogen in Small Rural Catchments," Agriculture, Ecosystems and Environment, Vol. 108, 2005, pp. 45-56.

[27] J. G. Arnold and P. M. Allen, "Estimating Hydrologic Budgets for Three Illinois Watersheds," Journal of Hydrology, Vol. 176, 1996, pp. 57-77.

[28] A. D. McElroy, S. Y. Chiu, J. W. Nebgen, A. Aleti and F. W. Bennett, "Loading Functions for Assessment of Water Pollution from Non-Point Sources," Environmental Protection Technology and Service, Environmental Protection Agency, 1976.

[29] J. R. Williams and R. W. Hann, "Optimal Operation of Large Agricultural Watersheds with Water Quality Constraints," Texas Water Resources Institute, Texas A\&M University Technical Report, College Station, No. 96, 1978.

[30] R. G. Menzel, "Enrichment Ratios for Water Quality Modeling," In: W.G. Knisel, Ed., CREAMS: A Field Scale Model for Chemicals, Runoff, and Erosion from Agricultural Management Systems Conservation Research Report, No. 26, 1980, pp. 486-492.

[31] "USDA Soil Conservation Service," Section 4: Hydrology, National Engineering Handbook, Washington, D.C., 1972

[32] J. E. Nash and J. V. Sutcliffe, "River Flow Forecasting Through Conceptual Models, Part 1: A Discussion of Principles," Journal of Hydrology, Vol. 10, No. 3, 1970, pp. 282-290.

[33] R. L. Bingner, C. E. Murphee and C. K. Mutchler, "Comparison of Sediment Yield Models on Watershed in Mississippi," Transactions of the ASAE, Vol. 32, No. 2, 1989, pp. 529-534.

[34] M. W. Liew and J. Garbrecht, "Hydrologic Simulation of the Little Washita River Experimental Watershed Using SWAT," Journal of American Water Resources Association, Vol. 39, No. 2, June 2007, pp.413-426.

[35] M. Rahman and I. Salbe, "Modelling Impacts of Diffuse and Point Source Nutrients on the Water Quality of South Creek Catchment," Environment International, Vol. 21, No. 5, 1995, pp. 597-603.

[36] A. Saleh, J. G. Arnold, P. W. Gassman, L. M. Hauck, W. D. Rosenthal, J. R. Williams and A. M. S. McFarland, "Application of SWAT for the Upper North Bosque River Watershed," Transactions of ASAE, Vol. 43, No. 5, 2001, pp. 1077-1087.

[37] B. Grizzetti, F. Bouraoui, K. Granlund, S. Rekolainen and G. Bidoglio, "Modelling Diffuse Emission and Retention of Nutrients in the Vantaanjoki Watershed (Finland) Using the SWAT Model," Ecological Modelling, Vol. 169, No. 1, 2003, pp. 25-38. 